\title{
Design and Fabrication of Membrane Less Microbial Fuel Cell (ML-MFC) using Food Industries Wastewater for Power Generation
}

\author{
Maksudur R. Khan ${ }^{1,2}$, M. S. A. Amin ${ }^{1}$, S. Sarker ${ }^{1}$, K. Ferdaus \\ ${ }^{I}$ Department of Chemical Engineering and Polymer Science, Shahjalal University of Science and Technology \\ ${ }^{2}$ Department of Chemical and Natural Resources Engineering, University Malaysia Pahang, 26300 Gambang, Pahang \\ Malaysia
}

\begin{abstract}
Electricity generation from the biodegradable organic substrate can be accompanied by wastewater treatment, which reduces the cost of industrial effluent treatment. In this study, effluent of local food-processing industries was treated in Membrane-Less Microbial Fuel Cell (ML-MFC) for electricity generation. Several investigations were conducted to enhance the current and voltage generation of MFC in different operating conditions, such as direct industrial effluent, adding drainage sludge concentration, aeration in cathode compartment, increasing the electrode area. In addition, COD removing capability of the ML-MFC was also studied. The study documented a maximum power density of $7.11874 \mathrm{~mW} / \mathrm{m}^{2}$ with the current density of $97.34 \mathrm{~mA} / \mathrm{m}^{2}$. COD removal was observed $47 \%$ to $74 \%$ in all experiments.
\end{abstract}

Key words: Microbial Fuel Cell, Bio-electricity, pH, COD

\section{INTRODUCTION}

Bangladesh is a developing country. In the last few decades, industrial boom occurred in this country. As a result, the industrial and the domestic energy needs are increasing exponentially day by day. However, the mainstream energy sources (gas, coal and oil) are not available in this country in the sufficient amount to meet the growing need. So this country is mostly dependent on the imported energy. Scarcity of energy is now the major obstacle in the way of industrial revolution of this country. Produced electricity at various plants in Bangladesh is lower than our present demand. This is the reason why we should focus into the renewable sources of energy. Another problem this country has faced recently is the growing amount of domestic and industrial wastes. As a third-world country, most of the industrialists do not pay respect to the government's environmental rules and regulations, and dispose wastes without prior treatment. Thus, the environmental pollution has been a headache for Bangladesh for recent years. This microbial fuel cell (MFC) technology can be the ultimate solution for these two major problems as it can produce electricity by utilizing wastes and minimize the wastewater treatment cost[1-4]. This is the most promising and compatible renewable source of energy for this country's perspective[5, 6]. So we can end this section by saying that, if we can develop MFC and imply it as an alternative power source, we may minimize our power scarcity as well as reduce the cost of waste water treatment and minimize the environment pollution[4, 7].

Microbial fuel cells (MFCs) are devices that use bacteria as the catalysts to oxidize organic and inorganic matter and generate current $[8,9]$. Electrons produced by the bacteria from these substrates are transferred to the anode (negative terminal) and flow to the cathode (positive terminal) linked by a conductive material containing a resistor, or operated under a load[10, 11]. MFCs converts' energy, available in a bio-convertible substrate, directly into electricity and operated efficiently at ambient, and even at low, temperatures distinguishing them from all current bio-energy processes[12]. It has been potential for widespread application in locations lacking electrical infrastructures and also to expand the diversity of fuels; we use to satisfy our energy requirements.

Commercial application of MFCs for wastewater treatment is difficult because the mediators are expensive and toxic in nature [13]. Hence, today emphasize is being given on development of the mediator less MFC, enhancing its power production, and reduction of its operational cost, to increase its acceptance as wastewater treatment process [2, 9, 14]. Furthermore, application of MFC in large scale for wastewater treatment containing suspended solids will be limited due to high initial cost of the membrane and fouling of the membrane requiring replacement [15]. The acceptability of MFC for wastewater treatment would increase, if use of membrane can be eliminated using some alternative [16]. In this paper, Membrane less Microbial Fuel Cell (ML MFC) was constructed by the locally available materials. Performance of the ML-MFC was studied under the different operating conditions such as varying sludge concentration, effect of aeration and $\mathrm{pH}$. Waste-water treatment potential of the ML-MFC was also been studied. 


\section{MATERIALS AND METHODS}

The Mediator less and membrane-less MFC was designed and fabricated in the laboratory using available local materials. It was made up of Polyacrylic having the effective height of $32 \mathrm{~cm}$ and width is 8.5 $\mathrm{cm}$. The sides attached with silicon and super glue. A sieve plastic plate is placed for support the glass wool and glass beads. Anode compartment (depth $16 \mathrm{~cm}$ ) was placed at bottom, and cathode compartment (depth 12 $\mathrm{cm})$ was at top. Glass wool (2 cm depth) and glass bead (2 cm depth) were placed at the upper portion of the anode compartment separating anode and cathode. Graphite rods obtained from the local factory were placed in anode and cathode compartment to be used as electrodes.

The total apparent surface area of the two anode electrodes was $70.37 \mathrm{~cm}^{2}$. The electrodes were connected with copper wire through the external resistance, ranging from $1.6 \Omega$ to $152 \mathrm{~K} \Omega$, excluding the resistance of copper connecting wire and a multimeter. Contact between electrodes and copper wires were sealed with epoxy material. The MFC was provided with an inlet and an outlet port.

Another port was provided for aeration through an aquarium pump. The food industrial wastewater used as fuel was supplied at a rate of 5 liter per day to the bottom of the anode compartment and the effluent left through the cathode compartment at the top of the MFC. The cathode compartment was aerated at a constant rate for the cathode reaction. The sludge was collected from Fulkoli food Industries Ltd, Sylhet. The cell was operated in batch mode at room temperature $\left(28 \pm 2^{\circ} \mathrm{C}\right)$.

\subsection{ML-MFC Operation}

The food industries wastewater used as fuel was supplied at a rate of $101 / \mathrm{d}$ to ML-MFC, which containing sucrose as a carbon source was used in the study. The cathode compartment was aerated at rate of $60 \mathrm{ml} / \mathrm{min}$ by an aquarium pump at an air pressure of $122 \mathrm{kPa}$. The ML-MFC was inoculated with anaerobic sludge collected from the local residential area's waste water drainage system. The inoculum sludge was sieved through $1 \mathrm{~mm}$ opening sieve and heated at $100^{\circ} \mathrm{C}$ for $15 \mathrm{~min}$ to suppress the methanogens, cooled at room temperature. No microbial addition was carried out in the cathode compartment. All the experiments were done in closed circuit, and the current generated was expressed as current vs. time. $100 \Omega$ external resistances was used to measure current in this thesis work The ML-MFC was operated at room temperature ranging from 29 to $33^{\circ} \mathrm{C}$.

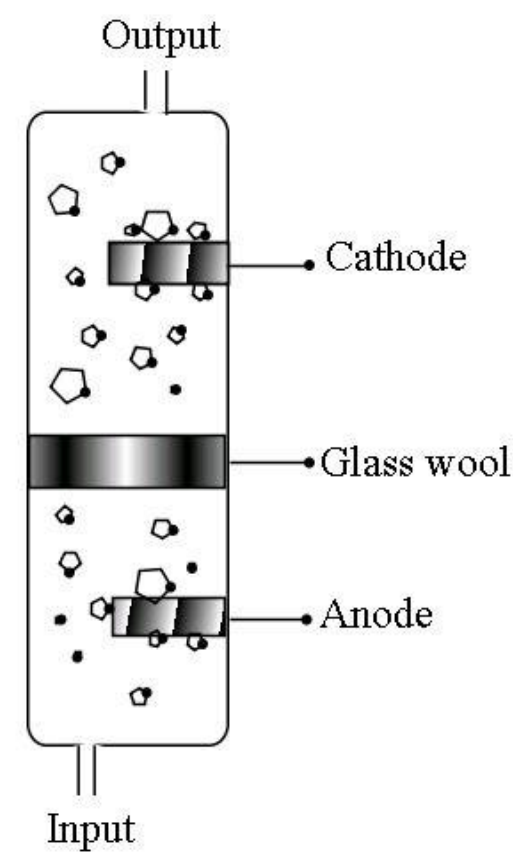

Fig. 1: Membrane-less microbial fuel cell

\subsection{Analytics and calculations}

Current (I) and potential (V) measurements were recorded using a digital multimeter (FL-9205A, SHENZHENXL electronic co. Ltd China) by connecting with $10 \Omega$ external circuit. Power (W) was calculated using relation $\mathrm{P}=\mathrm{IV}$, where $\mathrm{I}, \mathrm{V}$ represents current $(\mathrm{A})$ and voltage $(\mathrm{V})$, respectively. Current density $\left(\mathrm{A} / \mathrm{m}^{2}\right)$ was calculated by dividing the obtained power current by the anode surface area $\left(\mathrm{m}^{2}\right)$. COD and $\mathrm{pH}$ were monitored in the anodic chamber of MFC during operation according to the standard methods[3].

\section{RESULT AND DISCUSSIONS}

\subsection{Characterization of industrial wastewater}

Several experiments were conducted to find out the characteristics of raw sources. Following table listed some of the determined result.

\begin{tabular}{|l|l|l|}
\hline Parameter & Initial, mg/L & Final, mg/L \\
\hline SS & 356 & 8 \\
\hline DS & $70 \mathrm{mg} / \mathrm{L}$ & $61 \mathrm{mg} / \mathrm{L}$ \\
\hline TS & $436 \mathrm{mg} / \mathrm{L}$ & $69 \mathrm{mg} / \mathrm{L}$ \\
\hline$\%$ COD Removal & \multicolumn{2}{|c|}{$74 \%$} \\
\hline
\end{tabular}

\subsection{Effect of initial sludge loading}

In this experiment, the performance of ML-MFC was observed under various sludge loading conditions. Three ML-MFCs were run, which carried $100 \mathrm{ml} / \mathrm{L}$ sludge, $200 \mathrm{ml} / \mathrm{L}$ sludge and no external sludge. All operations were conducted with constant 3 pig aeration in cathode chamber and 5L/Day flow rate in the input of reactor. 


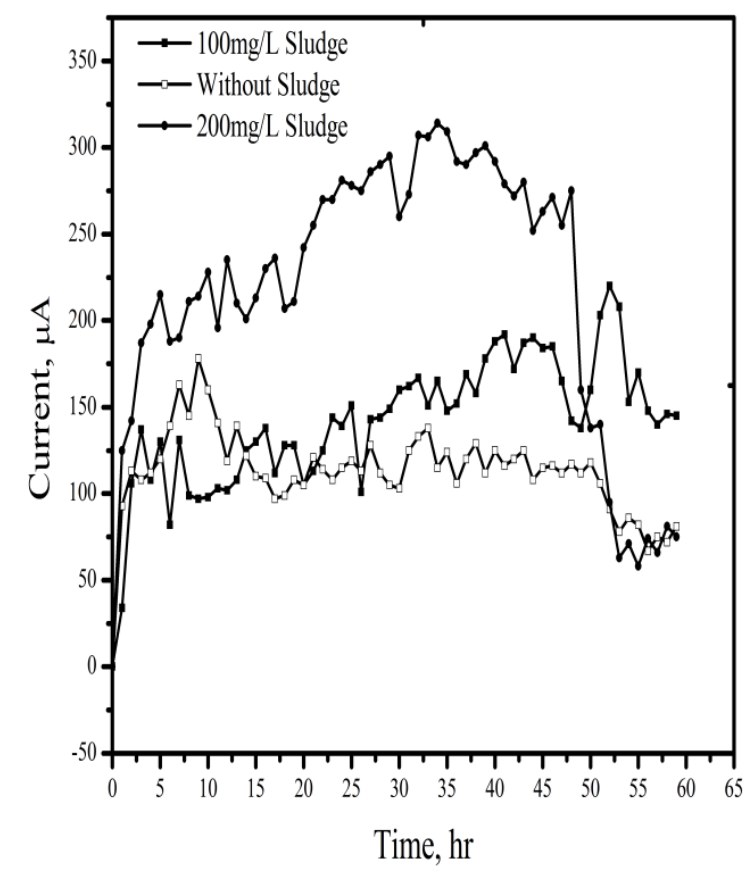

Fig. 2: Effect of current generation under various sludge concentrations in ML-MFC

From the Figure 2, we observed that initially the current generation was increased rapidly to almost $10 \mathrm{hr}$. After some period of that time, the electricity production was fluctuated in a certain range because of steady microorganism activity in the reactor as a catalyst to decompose organic substance.

The graph illustrates that, the batch used $200 \mathrm{ml} / \mathrm{L}$ drainage sludge at the influent showed better current production then other two. The maximum current generated was $314 \mu \mathrm{A}$ after $35 \mathrm{hr}$. After $50 \mathrm{hr}$, we used to recycle of the waste water for this process and obtained decreased electricity generation curve because in the recycle waste water, there was less organic substance compare to the initial feed water. The $100 \mathrm{ml} / \mathrm{L}$ drainage sludge contained effluent produced the highest $\mu \mathrm{A}$ current after $52 \mathrm{hr}$, whereas the fresh industrial effluent produced highest $178 \mu \mathrm{A}$ after $10 \mathrm{hr}$.

\subsection{Effect of aeration in the cathode}

To explore the effect of aeration in the cathode chamber on current production of Membrane less MFC, two different batch study of membrane less MFC was operated under certain conditions. The first batch was aerated in its cathode chamber with an aquarium pump at an air pressure of 3 psig. And the other batch was not aerated. The influent was feed at an average flow rate of
5L/day. The results are shown as current vs. time in the Figure 3.This figure clearly shows that, aeration in the cathode chamber has a great effect on current generation. Without cathode aeration, the generation of current shows a decreasing trend.

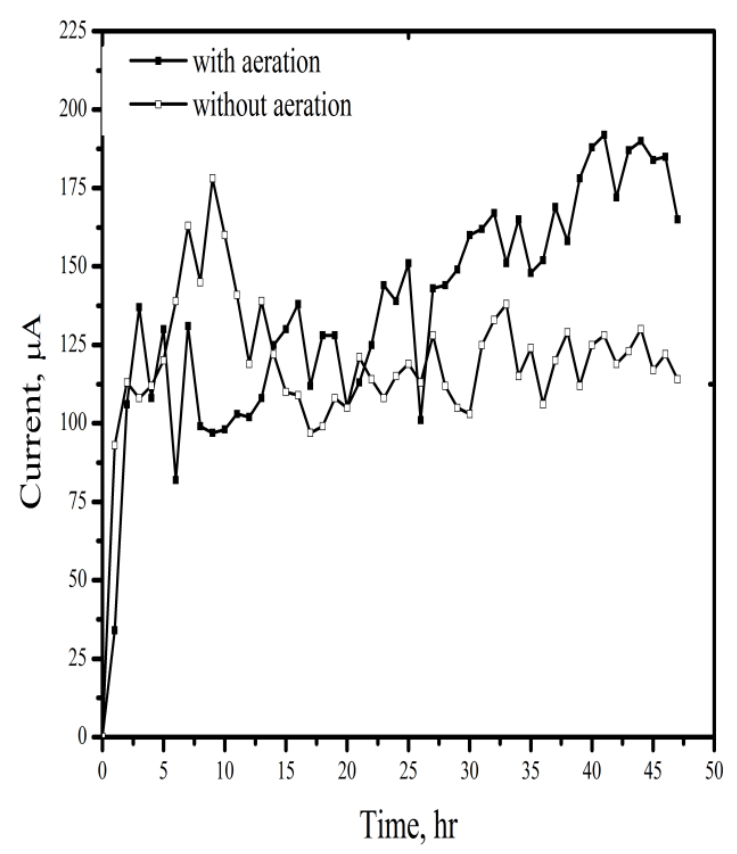

Fig. 3: Effect of the aeration in the cathode chamber on

$$
\text { ML-MFC }
$$

As the cathode compartment was not aerated, so the amount of dissolved oxygen in cathode compartment was decreasing with time and so proton attraction capacity was decreased, and that's why the current generation was decreased with time.

\subsection{Effect of electrode area in current generation:}

In this experiment, two cells were introduced where the electrode areas were fifty percent higher than the initial reactor's electrode area of $70.37 \mathrm{~cm}^{2}$ (anode+cathode). For fifty percent high electrode area the highest current was observed was $272 \mu \mathrm{A}$ after four hours.

However, for another reactor, the highest current observed was $314 \mu \mathrm{A}$ after $36 \mathrm{hrs}$. The high electrode area did not increase current generation because the reactor's volume contained a specific amount of foodprocessing wastewater. 


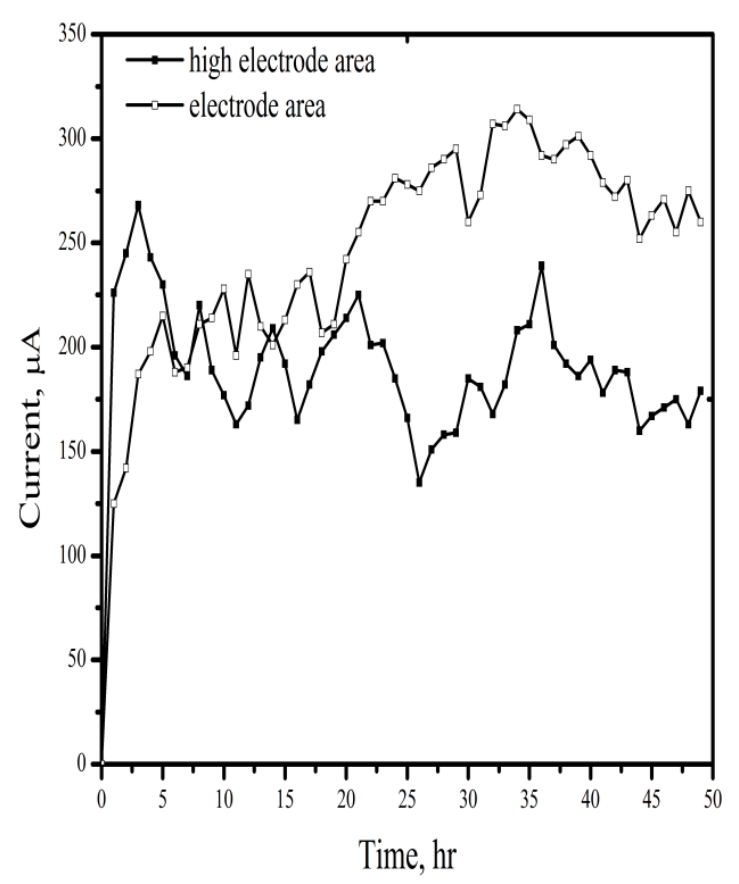

Fig. 4: Effect of the increased electrode surface area on the current production of Membrane less MFC

\subsection{Polarization \& Power Curve for ML-MFC:}

Figure 5 and Figure 6 shows the polarization curve and power density vs. current density curve for ML-MFC. The highest value of generated electricity was $314 \mu \mathrm{A}$ with $100 \Omega$ resistance. And this particular value was employed for calibrating the polarization curve. Under a $200 \mathrm{ml}$ external sludge load condition with aeration this highest point was obtained. Resistances, ranging between $10 \Omega-340 \mathrm{~K} \Omega$ were used to calibrate the polarization curve and power curve.

From the Figure 5, it is observed that, the current density of the cell increased when the cell potential decreased. Because when we applied low resistances, voltage is dropped and current generation is increased. Again when we increased the resistance voltage is increased whereas the current is dropped. The highest current density was $7.11874 \mathrm{~mA} / \mathrm{m}^{2}$, according to the voltage was $270 \mathrm{mV}$.

At first, the power densities showed an incremental trend with increasing external resistance. But after reaching a peak value, the power densities begin to fall down with increasing resistance and current density. Current generation showed decreasing trend with the increase in resistance and is consistent with the reported literature, which indicated a typical fuel cell behavior. At higher resistance used, relatively less power density was observed compared the current generation potentiality of different substrate and source inoculums.

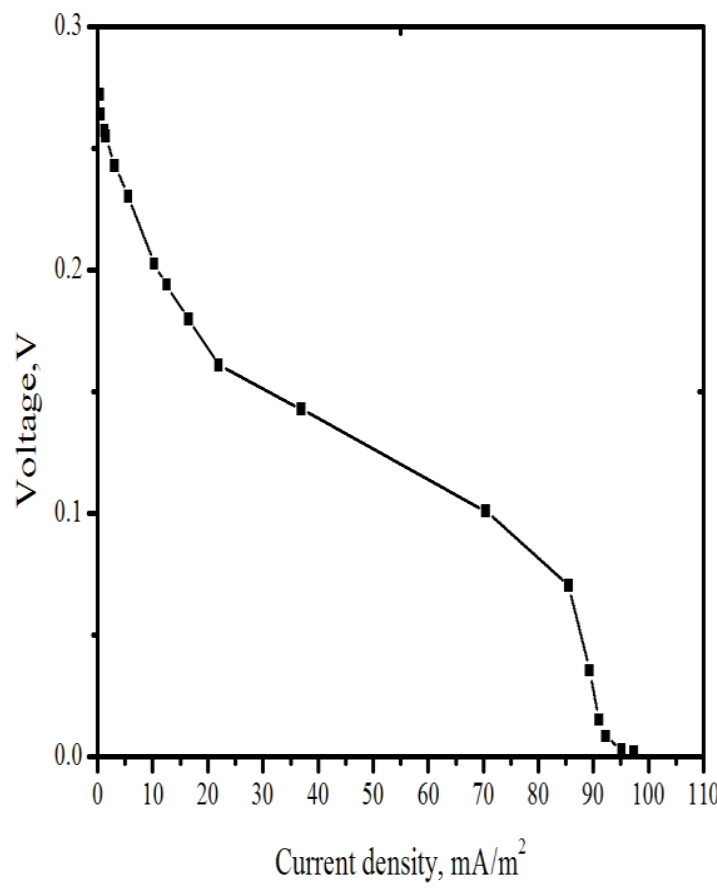

Fig. 5: Polarization curve

The power produced reported in our study is relatively moderate comparing to other researchers working with the same substrate. Relatively lower power observed in this study might be because of using the graphite electrodes without any coating.

\subsection{Removal of COD:}

COD is the Chemical Oxygen Demand which measures the amount of oxygen needed to decompose the organic substrates. COD of the waste water was measured in Oil-bath procedure just after its collection from a foodprocessing industry as well as after the MFC treatment.

When there are many microorganisms in the waste water, the COD becomes higher. Due to the presence of enormous microorganisms just after collecting waste water the COD values higher. In the MFC, the microorganisms metabolize the organic substrates resulting in a lower COD.

The COD removal efficiency is $58 \%$ without any sludge addition. In addition of $100 \mathrm{ml}$ sludge the efficiency becomes $63 \%$ while $200 \mathrm{ml}$ addition removes $74 \%$ of COD. Without the aeration in the cathode chamber, the efficiency is $47 \%$ while the vise-versa gives $58 \%$. All the values were measured initially and after a $48 \mathrm{hrs}$ treatment in MFC. 




Fig. 7: Removal of COD according to sludge and aeration effect

\section{Conclusion}

Membrane Less Microbial Fuel cell was fabricated and constructed from locally available materials. Effect of initial sludge concentration, aeration in cathode chamber and electrodes area are on electricity generation has been investigated. The study documented a maximum power density of $15.1214 \mathrm{~mW} / \mathrm{m}^{2}$ at current density of $97.34 \mathrm{~mA} / \mathrm{m}^{2}$. Polarization and power curves were plotted for particular sets of MFCs. Due to the ohmic resistances; sharp drop in the voltage was observed with the increase of the current density. This indicates the external resistances in electrode, connecting weir, circuit, etc. were dominated in the MFC efficiency. Maximum COD removal was attaining from $47 \%$ to $74 \%$ in all experiments. Further studies are necessary for the implementation of ML-MFC in practical uses.

\section{References:}

1. B.E. Logan and J.M. Regan, Microbial fuel cells: Challenges and applications, Environ. Sci. Technol., 41, (2006) 5172.

2.N.T. Trinh, J.H. Park, and S.S. Kim, Generation behavior of electricity in a microbial fuel cell, Korean J. Chem. Eng., 27, (2010) 546.

3. G. Gupta, B. Sikarwar, V. Vasudevan, M. Boopathi, O. Kumar, B. Singh, and Vijayaraghavan, Microbial fuel cell technology: A review on electricity generation, Journal of Cell and Tissue Reseearch, 11 (2011) 2631.

4.S.E. Oh and B.E. Logan, Hydrogen and electricity production from a food processing wastewater using fermentation and microbial fuel cell technologies, Water Res., 39, (2005) 4673.

5. B.E. Logan, et al., Microbial fuel cells: Methodology and technology, Environ Sci Technol, 40, (2006) 518.

6.D.R. Lovley, Bug juice: harvesting electricity with microorganisms, nature reviews microbiology, 4, (2006) 497.

7. L.T. Angenent, K. Karim, M.H. Al-Dahhan, B.A. Wrenn, and R. Domiguez-Espinosa, Production of bioenergy and biochemicals from industrial and agricultural wastewater, Trends Biotechnology, 22, (2004) 477.

8.D. Pant, G.V. Bogaert, L. Diels, and K. Vanbroekhoven, A review for the substrate used in microbial fuel cell (MFCs) for sustainable energy production, Bioresource Technology, 101, (2010) 1533.

9.B.E. Logan and B.E. Rittmaan, Opportunities for Renewable Bioenergy Using Microorganisms, Biotechnology and Bioengineering, 100, (2008) 203.

10. E. Katz, A.N. Shipway, and I. Willner, Handbook of Fuel Cells - Fundamentals, Technology and Applications 2003: Wiley.

11. B.H. Kim, I.S. Chang, and G.M. Gadd, Challenges in microbial fuel cell development and operation, Appl. Microbiol Biotchnol 76, (2007) 485.

12. R.H. Krishna, S.V. Mohan, A.V.V.S. Swamy, Z. Vishnuvardhan, P. Brahmajirao, and K. Sasidhar, Bio hydrogen production from industrial wastewater through anaerobic process in periodic discontinuous suspended growth reactor: influence of wastewater variation, International Journal of Chemical Sciences and Applications 1,(2010) 70.

13.F. Zhao, F. Hamisch, U. Schroder, F. Scholz, P. Bogdanoff, and I. Hermann, Application of pyrolysed iron (II) phthalocyanine and CoTMPP based oxygen reduction catalysts as cathode materials in microbial fuel cells, Electrochem. Commun, 7, (2005) 1405.

14. J. Sarasa, M.P. Roche, M.P. Ormad, E. Gimeno, A. Puig, and J. L.Ovelleiro, Treatment of a wastewater resulting from dyes manufacturing with ozone and chemical coagulation., Water Res., 32, (1998) 2721.

15. A.R. Rozendal, M.V.H. Hamelers, and N.C. Buisman, Effects of membrane cation transport on $\mathrm{pH}$ and microbial fuel cell performance, Environ. Sci. Technol., 40, (2006) 5206.

16. J. Sun, Y.Y. Hu, Z. Bi, and Y. Q.Cao, Simultaneous decolorization of azo dye and bioelectricity generation using a microfiltration membrane aircathode singlechamber microbial fuel cell, Bioresour. Technol., 100, (2009) 3185. 